\title{
Russian Image in History Textbooks of the Post-Soviet States: To the Question of Updating the Module «History of Russia» in the Concept of a Comprehensive Exam for Foreign Citizens in the Russian Federation as a Way of Adapting to Life in a Multicultural Society ${ }^{1}$
}

\author{
Marina Nikolaevna Moseikina \\ Dr. (History), Professor, Peoples' Friendship University of Russia, Russian Federation \\ Email:marina_moseikina@mail.ru
}

Doi:10.5901/mjss.2015.v6n1s2p48

\section{Abstract}

\begin{abstract}
The article analyzes school and high school history textbooks of several post-Soviet countries (Ukraine, Moldova, Armenia, Uzbekistan, Tajikistan), which have been studied in the frame of the test tasks assessment developed in the People's Friendship University for foreign nationals who are in compliance with federal law number 74 of the 1 January 2015 will have to pass a comprehensive exam in Russian language, Russian history and the basics of Russian Federation law. This applies to those who apply for the work permit, obtaining a patent, temporary residence and a residence permit on the territory of the Russian Federation. The analysis showed that the majority of post-Soviet countries went the way of teaching the younger generation through the nationalistic interpretation of history, creating textbooks where on the basis of anti-Russian sentiment form a mythological representation of the historical past of our nations. The article explains the meaning of inclusion in the test of the module "History of Russia" and the whole course of Russian history for foreigners as one of the most important means to adapt them to modern socio-cultural conditions in our country. It is emphasized that knowledge of historical traditions and cultural characteristics of the country of reception will promote a better understanding of Russian society and, consequently, the formation of a positive image of Russia.
\end{abstract}

Keywords: post-Soviet states, myths, colonialism, Russia's image, migration.

\section{Introduction}

After dissolution of USSR the management of new independent countries took serious measures on upbringing of the new generation in the spirit of new national ideology and devotion to the ruling regimes, in connection with which the issue of creation of the new text-books, first of all on the national history aroused, where on the background of antiRussian moods the confabulated views about historical past of our countries are formed. By means of simplification and archaism of historical approaches the negative image of Russia is formed first of all in the young generation of post-soviet states that transforms history in the tool of enmity. The report represented in 2008 according to the results of studied problem on the theme of "Highlighting the general history of Russian and peoples of post-Soviet countries in the schoolbooks of history of new independent states" states that: "If the existing tendencies continue, then in 15-20 years the events of XX century will be substantially forgotten by the population. In the consciousness of peoples of former USSR the image of Russia as ill-omened empire that for ages... suppressed and exploited them will be formed" (Bondarenko D.Ya., Vdovin A.I., Zhukov A.D. and etc., 2009).

However, namely Russia among former Soviet Republics in the last years became specific center of attraction of labour immigrants, in connection to which our country faced the task of promotion to social and cultural adaptation and integration of foreign citizens through respect to the state language, history and culture of Russian people. As a result of this according to the federal law No. 74 from April 20, 2014 the foreign citizens, desiring to employ themselves in Russia and receive temporary residence permit or residence card, along with owning of the Russian language must assimilate and confirm knowledge of history of Russia and bases of RF legislation by means of passing the corresponding exam since the $1^{\text {st }}$ January in 2015 (Rossiiskaya gazeta, 2014). This direction in Conception of migration policy of modern Russia has important meaning as the presence of considerable quantity of foreigners, which had no possibility of fullfledged adaptation to the cultural and social conditions of the residence country, provokes tension in the society and creates potential threat to the international agreement (Moseikina M.N, 2014).

1 The scientific publication was prepared at supporting of the Ministry of Education and Science of the Russia Federation within the frameworks of execution of scientific-methodical works in 2014. No. 10.9063.2014 
Inclusion of module "History of Russia" in the content of complex exam for foreign citizens is understood as especially important in the light of what was mentioned above. Within the preparation to passing exam the idea that Russia was created by the representatives of different peoples and confessions must become leitmotif of history teaching especially for citizens of post-Soviet states, and the formed cooperation tradition, having received new impulse of development, must become one of the decisive factors of their spiritual and everyday integration. As a result of history study the feeling of own demand in the Russian society, on the one part, and responsibility for future relations between peoples, on the other part, must form.

\section{Discussion}

In the last years in the native historiography the interest to the content of national history of post-Soviet states in the period of their being in the content of Russian Empire and USSR is evident (Chubar'yan A.O. and etc., 1999). However, in connection with introduction of complex exam since the $1^{\text {st }}$ January in 2015 in the RF for foreign citizens on Russian language, history of Russia and bases of legislation as a means of adaptation of immigrants on the territory of the Russian Federation, this aspect was not dealt that in many respects conditioned actuality of this research.

The authorities of former republics of USSR, presently independent states, actively deal with the development of their national ideology and search of the national identity, determination of the place of own country in the modern world. At that as G. Bordyugov and V. Bukharev fairly state that "political appropriateness, dictated by the dissolution of USSR, determined similar tendencies in writing new histories", as a result of a number of most actual themes the "theme of ethnic state order and ethnic territories" was advanced (Bordyugov G., Bukharev V.). The majority of former countries of USSR on the way of teaching nationalistic interpretation of history to the growing generation based upon the myths about antiquities of own people, high cultural mission of ancestors and formation of extremely negative views about the Russian state and Russian people in the pupils.

As a result for the years of sovereignty of independent countries of former USSR on the post-soviet space the generation formed, which owing to the historical education began to perceive Russia exclusively as empire, as the source of modern grieves and sufferings of these countries. Teaching of history in the range of countries, for example, in the Baltic States and Ukraine became the means not only of abstraction of attention of youth from the real internal reason of heavy state of the country, but sewerage of its negative energy on its neighbor - Russia. So it is very important that people, who came in Russia from different countries and are bearers of different languages, cultures and religions, could receive knowledge necessary for adequate understanding of the social-cultural environment, which surrounds them for overcoming ethnic isolation and equitable communication both with local inhabitants and with each other.

In this connection according to the "Requirements to minimal level of knowledge, necessary for passing exam in the Russian language as foreign one, history of Russian and bases of legislation of the RF" accepted by the Ministry of Education and Science of RF (Decree of the Ministry of Education and Science of the RF, 2014), as well as with taking into account the basic contingent of foreign citizens, who arrived presently on the territory of RF, the analysis of textbooks and school-books of the range of post-Soviet states (in particular, Ukraine, Moldavia, Armenia, Tajikistan, Uzbekistan) in connection with highlighting such problems as joining of these territories to Russia, interaction of peoples inside the single country, soviet period in the history of the national states, when people of different nationalities overcame hard difficulties (revolutions, wars), which fall on their life, and as a result created conditions for gradual development of the country.

In its turn, the acquaintance with material of the text-books on the national history allows stating the fact that for many of them distortion or concealment of the essential facts is typical and subjective, often negative estimations of events connected with Russia that gives no possibility to see the single picture of what happened and understand the motives of activity of the participants of those events.

Thus, in modern Ukrainian text-books the theory of existence of "ancient Russia nationality" in the period of Kyivan Rus, from which later the Great Russian, Ukrainian and Belarus nationalities appeared. The scheme of M.S. Grushevsky is offered in them, which key moment is statement about parallel existence of two nationalities: "Ukrainian-Russian" and "Great Russian". It goes about "History of Ukraine-Rus" (although the states with such name never existed) and "History of Moskovia or Great Russia" (The coverage of history of Russia and peoples of post-soviet countries). Based upon this at young generation of Ukrainians the persuasion in the separated history of Ukrainians, Belarusians and Russian is formed; the schoolchildren and students are commanded with idea of existence of some Ukrainian state system with ancient times (in this connection "The Ukrainian Cossack State" (Vlasov V., 2002), of "Hetman Ukraine" of B. Khmelnitsky (Boiko O.D., 2008, Zhuravlyov D.V., 2013) is named. In the range of Ukrainian text-books the reunion of Ukraine with Russia is given as acknowledgement of independence of Ukraine by Moscow. In the modern context the significance of 
Pereyaslav Rada of 1654 year is reduced, as the Rada only showed "readiness of the Ukrainian party" to sign "interstate Ukrainian-Moscow Treaty", that was signed in Moscow on March in 1654. According to the treaty Ukraine seemingly was recognized as independent state. In reality, as the native researchers mark, this is a myth of modern Ukrainian historiography, replicated in the text-books of history.

In the scientific and teaching literature of Moldavia the issue about joining of Bessarabia to Russia in 1812 year on the conditions of Bucharest Peace Treaty of Russia and Turkey received different interpretations: both as annexation and as freeing and expectations accomplishment of Moldavia population, as until now the notion of "Moldavian nationality" was not determined inside the discourse of national historiography, in which the opposition of so-called Romania and Moldavia supporters takes place. The first one, considering Moldavians as a part Romania nation, see occupants in the Russian people, beginning since 1812, and policy of Russia is considered by them as policy of systemic suppression of national traditions and culture, destruction of the territory in the period of Russian-Turkish wars; in this connection the role of Russia on Balkan Mountains, significance for Danube principalities for states of Kucuk Kaynarca, Jassy, Adrianople treaties between Turkey and Russia (Bordyugov G., Bukharev V).

For Moldavia supporter, on the opposite, the principal events are the events, connected with the birth of Moldavian state with the period of ruling of Peter I in 1812 year, events of 1918-1940 years, Great Patriotic War, being in the content of USSR and time of country flourishing. However, on the modern stage of Moldavian state neither Romania movement, not Moldavia movement in that understanding, in which they were present in the end of 1980-s - beginning of 1990-ss can't claim for the right to be called as ideology of the national state (Oleinik L.G., 2014).

As a result even through two decades after obtainment of independence by the country, the authorities of Moldavia still can't clarify themselves, the history of which nation Moldavia school-children must study as the native one. Since 1991 up to 2006 here the course of "History of Romanians" was taught. Since 2006 the communists introduced disciplines "Integrated history" within the frameworks of official discipline "History", according to recommendations of the European Council. According to the opinion of specialists of this organization, the course "History of Romanians" was tendentious, negatively influences on the public atmosphere and contained grains for inflaming of interethnic hatred. However, the European recommendations on teaching of history in XXI century was supported in Moldavia not for long. In 2009 in the schools teaching of "History of Romanians" was taught.

In the text-book of Moldavian authors Ozhog I.A. and Sharov I.M. the administrative arrangement of Bessarabia that entered into the content of the Russian Empire as a result of Russia-Turkish war of 1806-1812 year was analyzed, as well as the peculiarities of social-economic and political development of the country. It was pointed out that the specificity of administrative system in Bessarabia was fixed in "the Rules of temporary ruling of Bessarabia", according to which in the territory the local customs were preserved, and "record keeping... was conducted in two languages - Russian and Romanian"; "the native language was also kept in schools and churches" (Ozhog I.A., Sharov I.M., 1997). The successes of Bessarabia were marked after entering of the agricultural and transport development area into Russia. Together with it, speaking about disadvantages of internal policy of tsarism in Bessarabia (country colonization, intensified implementation of the Russian language, limitation of peasants' movement for residence in cities etc.), the authors call all this as "aspects of colonial policy, conducted by the autocracy in the country", and make one-sided conclusion about that this was "empire policy, directed on the gradual russification of the local population" (Ozhog I.A., Sharov I.M., (1997).

In the range of Central Asian Republics, for example, in Uzbekistan, pre-revolutionary Russia, and then USSR also arise as empire states, which used Central Asian region only as the source of cheap raw material, suppressed the national-liberation aspirations of its peoples, and as a result, condemned them for economic retardation (Alimov D. A., 2010). In connection with this in the scientific literature the notion of "colonial policy of the Russian Empire in Turkestan country" is widely used, which essence according to the authors' opinion was directed "on: ignoring the political and civil rights of local population; transformation of the Central Asia in the raw material base of Russia; limitation of the country from penetration of the progressive tendencies and advanced culture" (Arifdzhanov E. K. and etc., 2012).

At the same time in the text-book on the "History of Tajik nation", recommended by the Ministry Education of Tajikistan Republic, the presence of political and trade relations of Russia with the region of Central Asia already in XVIII century is marked as the positive fact (it is told that "Peter I made a lot for that"). The authors make conclusion about that population of Central Asia rid itself "from all horrors of feudal wars in 60-s years of XIX century, after joining the territory to Russia", similarly as a result of treaty conclusion between Russia and Bukhara in 1868 year, the slavery and captive trade was marked in the Kokand khanate. Nevertheless, wholly the policy of Russia on the territory of the established Turkestan general-government is determined by the authors as "colonial" one, as according to their opinion, the Russian capitalists looked at the Central Asia exclusively as "on own colony, which they needed first of all as the source of raw material for the Russian industry" (Litvinskii B.A., Mykhtorov A., 1992).

However, in fact it is important to point out that although the national policy of Russia was not deprived by 
contradiction, nevertheless, having established the strict political control over joined territories, the Russian authorities invested a lot of funds and efforts into them. In the report of tsar minister A.V. Krivoshein in relation to Turkestan it was marked that in the period of country possession cost Russia more than $140 \mathrm{mln}$. RUB, not counting "extraordinary" expenses, for example, construction of the railway that cost treasure $164 \mathrm{mln}$. RUB in 1909 (that made only 1/136 part of profits, received by Russia in this year, i.e. less than one per cent) (Litvinov P.P., 2014). Moreover, the elements of slavery, fractionalism and internal conflicts kept on the country territory were liquidated.

The Russian government also understood the significance of Muslim religion to East nations and that's why it displayed toleration. In 1886 the Muslims were equaled in the rights with Orthodox believers. Here the Russian-native schools, men's progymnasiums for teachers' training were opened. Upon the initiative of the first Turkestan generalgovernor K.P. von Kaufmann, the National theatre and public library were opened in Tashkent. All these measures promoted to distribution not only Russian, but high society National culture on the territory, and by no means prevent "penetration of the progressive tendencies and advanced culture" on the territory of Turkestan, in which the authors of the above cited text-book try to convince their students.

More objectively the history of joining of Eastern Armenia to Russia appears in the text-books on history of Armenian people, where particularly Turkmenchay treaty of 1828 year between Russia and Persia (Iran) in accordance to which this joining took place, was called "prominent success of Russian" that "strengthened position of Russia on Caucasus, resulted in fixing of the Eastern Armenia for Russia, in the content of which the Armenian nation began to develop relatively more liberally". In connection to this the authors highly evaluate the policy of pre-revolutionary Russia on repatriation of Iran Armenians on the historical homeland; at that the special role in resettlement of the Armenian population is given to the Russian writer and diplomat A.S. Griboedov.

However, the history of soviet period that is represented mainly through the prism of "Bolshevik experiments", policy of Stalin's terror, repressions and deportations is subjected to the strong falsification in the educational publications of states of former Soviet Union.

In the modern Ukrainian school and higher educational establishment text-books the history of Revolution of 1917 year and Civil war in Russia (1918-1920 ss.) is most frequently considered through the prism of "national-liberation fight", and the term "Civil war" in the Ukrainian text-books on history is thus substituted for formulation "Ukrainian National-Democratic Revolution" or "Ukrainian Revolution" with the same dating 1917-1920 years. (Boiko O.D.; Vlasov V.S., 2013). Thus, the view on history of Russia as a foreign state that has no general historical process with Ukraine, is imposed on pupils. The theme Holocaust of 1932-1933 years in Ukraine is the central theme of historiography of history of XX century the range of countries of post-Soviet space, as the text-books state, artificially organized by Moscow and which in accordance with the official version of Ukraine's authorities is considered "as display of genocide" of the Ukrainian nation (Sharov I., Kashu I., Dobzeu M. and etc., 2013). Meanwhile, it was established that this period of mass starvation on the territory of USSR, which led to victims of not only inhabitants of Ukraine, but Belorussia (BSSR), Northern Caucasus, Volga region, Southern Ural, Western Siberia and Kazakhstan.

The soviet history in the text-books of the range of Republic of Central Asia along the analogy with prerevolutionary one is frequently shown from one side and as "colonial" that finds reflection in the names of section of textbooks, such for example as "Establishment of colonial authority in the form of socialistic state in Turkestan. The movement of fighters for freedom"; "Economic and cultural policy in the period of socialism, its colonial essence. Repression policy" and etc. (Arifdzhanov E. K. and etc., 2012).

One important problem that in the Soviet history of $X X$ century deserves special attention is the history of Great Patriotic war. However, from the majority of text-books on the territory of post-Soviet space this notion has gone, today they prefer to write exclusively about Second World War in them (Sharov I., Kashu I., Cherbushka P. and etc., 2013). Moreover, in the course of western orthodox historiography, the ideal of equal responsibility of Stalin and Hitler for unleashing the Second World War is imposed on the lessons to the young generation (first of all republics of the Baltic states, Georgia, Ukraine) with reference of Molotov-Ribbentrop pact. On the assumption of this, the liberate and fair character of Soviet nation fight against Nazi Germany was reconsidered, and on the contrary, both fighters with Stalin's regime (with "Soviet repression machine") and nationalists (for example, URA) and collaborators, which cooperated with Nazis and participated in the punitive operations on the occupied territories were rehabilitated (Ozhog I.A., Sharov I.M.).

In connection with highlighting the post-war history of Soviet Republics (for example, Moldavian SSR, Uzbek SSSR, Tajik SSSR), the successes achieved in the period of 1950-80-s years are marked in the development of industry, agriculture, science and education. Together with it, unjustified location of many enterprises on the territory of Republic, the authors again try to connect one migration of staff and other problems with "the next stage of colonial policy in relation" to one or other "national outskirts of empire" (Ozhog I.A., Sharov I.M.).

Along with it in the text-books of Armenia at consideration of the Soviet period of the Republic history is signed in 
the history of big country, the authors show both positive changes in life of Armenian people and difficulties, which fall on the destiny of whole Soviet nation, including Armenian one. There pages devoted to the results of industrialization and problems of collectivization in Armenia in the text-books, and special section devoted to the Soviet Armenia in the years of Great Patriotic War.

\section{Results}

Thus, as the considered material showed after dissolution of USSR, in the new independent states the text-books on the national history were created, in which on the background of anti-Russian moods the confabulated views about historical processes in the new independent states were frequently formed. In fact, in all of them (with exception of Belorussia and partially Armenia) in one or other extent the nationalistic approaches to the history of Russia triumph. Naturally, that having found oneself in the Russian Federation with biased view on the history and modern policy, it will be difficult for foreign citizen to estimate and tolerantly perceive the social and cultural environment surrounding it that can be the obstacle on the way of its adaptation to the conditions of life in the Russian society and among Russians.

In connection to this, the inclusion of "History of Russia" in the complex exam for foreign citizens and first of all from the post-Soviet states seems to be the most important. The long-term staying of immigrants from CIS countries in Russia evidences about that the knowledge of one Russian language is not enough for their adaptation. For orientation in the social-cultural space of the country it is necessary at least on the minimal level to study its traditions, bases of history and culture of nations living here. It is important to form in foreign citizens, who went to the modern Russia, the whole view about basic stages of its historical development, peculiarities of interrelations of the Russian nation with nations, which entered into the content of the Russian Empire and USSR, get them acquainted with their labour and military deed that finally will help to form objective view about Russia's contribution in the development of the world history and culture.

\section{References}

Alimov D.A., (2010). History of Uzbekistan. Test-book for 9 form of secondary educational schools. Tashkent,. P. 160. [online] Avaible : http:// http://www.fergananews.com/articles/7112 (August 17, 2014 )

Arifdzhanov E. K. and etc., (2012). History of Uzbekistan: Course lectures Tashkent. Academy of MIA of Uzbekistan Republic. P. 142, 180.

Boiko O.D., (2008). History of Ukraine. Text-book. 3d edition, revised, Kyiv: Akademvydav. P. 130-144; C. 151-163.

Boiko O.D. Specified works. P. 316-365.

Bondarenko D.Ya., Vdovin A.I., Zhukov A.D. and etc.(2009). The coverage of history of Russia and peoples of post-soviet countries in the school text-books of the new independent states, M.: State club (Nation. laboratory of international policy). P. 12.

Bordyugov G., Bukharev V. Specified works. P. 121, 149.

Chubar'yan A.O. and etc., (1999). European experience and teaching in history in the post-Soviet Russia. M.: Institute of Universal History of RAS, P. 314.

Decree of the Ministry of Education and Science of the RF, (2014). No. 1156. "About statement of form, order of exam conduction on the Russian language as a foreign one, history of Russia and bases of legislation of the Russian Federation and requirements to the minimal level of knowledge, necessary for passing the specified exam". [online] Avaible: http://www.garant.ru/hotlaw/ federal/564308/ (August 29, 2014)

Litvinov P.P., (2014). About integrity of history of Russia in time and space /Teaching of native history.

Historical facts and their interpretation. Materials of XVIII All-Russian conference, Moscow, PFUR, May15-16, 2014. M.: Publ.-house "Econom-inform". P. 135-136.

Litvinskii B.A., Mykhtorov A., (1992). History of Tajik people (8|9), Dushanbe: MAORIF. P. 69-99.

Moseikina M.N, (2014). Conception of the complex exam on the Russian language, history and bases of legislation for labour immigrants in the RF as the factor of immigration security. P. 345.

Oleinik L.G., (2014). Historical conditionalities of constituting the state system and national identity of the Moldova Republic in the educational courses on history /National history teaching. Historical facts and their interpretation. Materials of XVIII of All-Russian conference, Moscow, PFUR, May 15-16, 2014. M.: Publ.-house "Econom-inform". P. 200-201.

Ozhog I.A., Sharov I.M., (1997). History of the Romanians. Brief course of lectures. Kishinev: Moldavia State University. P. $122,125$.

Ozhog I.A., Sharov I.M. Specified works. P. 183, 190-191.

Rossiiskaya gazeta, (2014). On Legal Provision of foreign citizens in the Russian Federation No. 74-FZ. [online] Avaible: http://www.rg.ru/2014/04/23/inostrantsy-dok.html (april 24, 2014)

Sharov I., Kashu I., Dobzeu M. and etc., (2013). Kishinev: Cartidact. P.18.

Sharov I., Kashu I., Cherbushka P. and etc., (2013). History of the Romanians and universal history. Textbook for 9th form. Kishinev: Cartidact,. P. 61.

The coverage of history of Russia and peoples of post-soviet countries. P. 29-30. 
Vlasov V. S., (2002). History of Ukraine. $8^{\text {th }}$ form. Kiev, P. 35, 126-130, 144-148 and etc.

Vlasov V.S., (2013). History of Ukraine (Introduction into history): text-books for $5^{\text {th }}$ form of secondary educational establishments. Kiev: Genesis. P. 137-141.

Zhuravlyov D.V., (2013). 100 key events of the Ukrainian history. Kharkiv: Klub simeinogo dozvillia. P. 121-202. 